\title{
Pendampingan Posyandu Bayi dan Balita di RW di Kelurahan Bendan Dhuwur Kecamatan Gajah Mungkur Kota Semarang
}

\author{
IndahSulistyowati ${ }^{1}$, Oktaviani Cahyaningsih ${ }^{1}$, Novita Alfiani ${ }^{1}$ \\ UUniversitas Widya Husada Semarang \\ e-Mail: indahs_17610@yahoo.com, oqt4_viani@yahoo.co.id, novitaalfians29@yahoo.co.id
}

\begin{abstract}
ABSTRAK
Posyandu dibentuk oleh masyarakat desa/kelurahan dengan tujuan untuk mendekatkan pelayanan kesehatan dasar, terutama Kesehatan Ibu dan Anak (KIA), Keluarga Berencana (KB), imunisasi, gizi, dan penanggulangan diare kepada masyarakat setempat. Kegiatan rutin posyandu diselenggarakan dan dimotori oleh kader posyandu dengan bimbingan teknis dari petugas kesehatan. Peran kader saat ini hanya menimbang bayi jika balita datang ke posyandu dan memberi PMT (pemberian makanan tambahan). Dan keberhasilan posyandu tak lepas dari kerja keras kader yang dengan sukarela mengelola posyandu di wilayahnya masing-masing. Kurangnya pelatihan dan pembinaan keterampilan memadai bagi kader menyebabkan kurangnya pemahaman tugas kader, lemahnya informasi serta koordinasi antara petugas dalam kegiatan posyandu dapat mengakibatkan kurangnya tingkat kehadiran balita ke posyandu. Kelangsungan posyandu tergantung dari partisipasi masyarakat itu sendiri. Oleh karena itu upaya yang perlu dilakukan dalam rangka meningkatkan peran kader posyandu yaitu dengan cara diadakanya pelatihan kader posyandu. Penyelenggaraan pelatihan kader dapat dilakukan oleh masyarakat itu sendiri yang berkoordinasi dengan petugas kesehatan dan melibatkan sektor lain di bawah bimbingan puskesmas, sedangkan metode yang digunakan disesuaikan dengan tujuan pembelajaran yang diharapkan, setelah melakukan pelatihan kader rencana tindak lanjutnya dengan melakukan evaluasi serta aplikasi atau penerapan hasil pelatihan di masyarakat. Sedangkan untuk meningkatkan sikap serta ketrampilan yang dilatihkan harus disesuaikan dengan tugas kader dalam meningkatkan program kesehatan di desa kader. Pelatihan yang dimaksudkan itu adalah kemampuan kader dalam pelaksanaan kegiatan yang berkaitan dengan kesehatan
\end{abstract}

Kata kunci: pendampingan, posyandu, bayi dan balita

\section{ABSTRACT}

Posyandu is formed by the village / kelurahan community with the aim of bringing basic health services closer, especially Maternal and Child Health (KIA), Family Planning (KB), immunization, nutrition, and diarrhea prevention to the local community. Posyandu cadres are organized and driven by Posyandu cadres with technical guidance from health workers. The role of cadres at this time is only to weigh babies if the toddler comes to the posyandu and provides PMT (supplementary feeding). And the success of posyandu cannot be separated from the hard work of cadres who voluntarily manage posyandu in their respective areas. Lack of adequate training and skills development for cadres causes a lack of understanding of cadres' duties, weak information and coordination between officers in posyandu activities can result in a lack of toddler attendance at the posyandu. The posyandu's sustainability depends on the participation of the community itself. Therefore, the effort that needs to be done in order to increase the role of posyandu cadres is by holding Posyandu cadres training. Implementation of cadre training can be carried out by the community itself in coordination with health workers and involving other sectors under the guidance of the health center, while the methods used are adjusted to the expected learning objectives, after conducting cadre training the follow-up plans are carried out by evaluating and applying or implementing the training results. in society. Meanwhile, to improve the attitudes and skills that are trained, it must be adjusted to the duties of cadres in improving health programs in the village cadres. The training that is meant is the ability of cadres in carrying out activities related to health.

Keywords: mentoring, posyandu, infants and toddlers 


\section{PENDAHULUAN}

Posyandu dibentuk oleh masyarakat desa/kelurahan dengan tujuan untuk mendekatkan pelayanan kesehatan dasar, terutama Kesehatan Ibu dan Anak (KIA), Keluarga Berencana (KB), imunisasi, gizi, dan penanggulangan diare kepada masyarakat setempat. Kegiatan rutin posyandu diselenggarakan dan dimotori oleh kader posyandu dengan bimbingan teknis dari petugas kesehatan. Jumlah minimal kader untuk setiap posyandu sebanyak 5 orang sesuai dengan jumlah kegiatan utama yang dilaksanakan oleh posyandu dengan sistem layanan 5 meja atau 5 langkah kegiatan, yaitu: (1) Pendaftaran; (2) Penimbangan; (3) Pencatatan/pengisian Kartu Menuju Sehat (KMS); (4) Penyuluhan; dan (5) Pelayanan kesehatan sesuai kewenangannya (Depkes RI, 2006).

Peran kader saat ini hanya menimbang bayi jika balita datang ke posyandu dan memberi PMT (pemberian makanan tambahan). Dan keberhasilan posyandu tak lepas dari kerja keras kader yang dengan sukarela mengelola posyandu di wilayahnya masing-masing. Kurangnya pelatihan dan pembinaan keterampilan memadai bagi kader menyebabkan kurangnya pemahaman tugas kader, lemahnya informasi serta koordinasi antara petugas dalam kegiatan posyandu dapat mengakibatkan kurangnya tingkat kehadiran balita ke posyandu. Kelangsungan posyandu tergantung dari partisipasi masyarakat itu sendiri.

Upaya yang perlu dilakukan dalam rangka meningkatkan peran kader posyandu yaitu dengan cara diadakanya pelatihan kader posyandu. Penyelenggaraan pelatihan kader dapat dilakukan oleh masyarakat itu sendiri yang berkoordinasi dengan petugas kesehatan dan melibatkan sektor lain di bawah bimbingan puskesmas, sedangkan metode yang digunakan disesuaikan dengan tujuan pembelajaran yang diharapkan, setelah melakukan pelatihan kader rencana tindak lanjutnya dengan melakukan evaluasi serta aplikasi atau penerapan hasil pelatihan di masyarakat. Sedangkan untuk meningkatkan sikap serta ketrampilan yang dilatihkan harus disesuaikan dengan tugas kader dalam meningkatkan program kesehatan di desa kader. Pelatihan yang dimaksudkan itu adalah kemampuan kader dalam pelaksanaan kegiatan yang berkaitan dengan kesehatan.

\section{METODE \\ Kegiatan}

1. Pemberian Materi

Pemberian materi kepada kader posyandu bayi dan balita. Adapun materi yang disampaikan adalah :
a. Tujuan Posyandu
b. Kegiatan Pokok Posyandu
c. Kriteria Kader Posyandu
d. Pelaksanaan Kegiatan Posyandu, diantaranya adalah :

1) Posyandu dilaksanakan sebulan sekali yang ditentukan oleh Kader, Tim Penggerak PKK Desa/Kelurahan serta petugas kesehatan dari Puskesmas, dilakukan pelayanan masyarakat dengan sistem 5 meja yaitu :

Meja I : Pendaftaran.

Meja II : Penimbangan

Meja III : Pengisian KMS

Meja IV : Penyuluhan perorangan berdasarkan KMS

Meja V : Pelayanan KB \& Kes : Imunisasi, Pemberian vitamin A Dosis Tinggi berupa obat tetes ke mulut tiap bulan Februari dan Agustus, Pembagian pil atau kondom, Pengobatan ringan, Kosultasi KB-Kesehatan

2) Petugas pada Meja I s/d IV dilaksanakan oleh kader PKK sedangkan Meja $\mathrm{V}$ merupakan meja pelayanan paramedis (Jurim, Bindes, perawat dan petugas $\mathrm{KB}$ ).

\section{Pendampingan Kader}

Melaksanakan pendampingan pada Kader Posyandu Bayi dan Balita dalam melaksanakan tugas-tugasnya. Pendampingan dilaksanakan saat Kader Posyandu melaksanakan kegiatan posyandu yang dijadwalkan satu bulan sekali.

\section{Rancangan Evaluasi}

Evaluasi dan monitoring dilakukan penilaian yang dilakukan oleh tim penyelenggara kegiatan. Kegiatan tersebut dilakukan tiga kali dalam satu tahun, yakni pada bulan kempat, kedelapan, dan bulan ke12. Tujuan evaluasi untuk melihat sejauhmana program berjalan sesuai dengan target dan outcomes yang diharapkan. Berikut bentuk evaluasi yang dikembangkan :

Indikator Proses

1. Peserta pelatihan menguasai teori tentang posyandu bayi dan balita

2. Peserta terampil dalam melaksanakan posyandu bayi dan balita 
3. Peserta mampu mengembangkan potensi diri.

4. Peserta dapat mengaplikasikan ilmu yang diperoleh dari pendampingan

Indikator Outcome

1. Kualitas Pelayanan Posyandu Balita Meningkat

2. Pertumbuhan dan Perkembangan Balita Terpantau

\section{HASIL DAN PEMBAHASAN}

Kegiatan Pendampingan Posyandu Bayi dan Balita telah dilaksanakan dengan hasil kader posyandu mampu mengaplikasikanya ketrampilannya dalam pelaksanaan posyandu bayi dan balita. Sehingga dengan ketrampilan ini kader mampu bekerja lebih baik dalam melaksanakan kegiatan posyandu bayi dan balita di RW II Kelurahan Bendan Dhuwur Kecamatan Gajah Mungkur Kota Semarang.

Kegiatan pemberian materi pada kader posyandu bayi dan balita telah dilaksanakan dengan hasil sudah diberikan materi yang terdiri dari materi tentang posyandu dan pelaksanaan kegiatan posyandu. Dimana sebelum pemberian materi dan setelah pemberian materi dilaksanakan pre test dan post test dengan hasil sebagai berikut :

Tabel 1. Pengetahuan Tentang Posyandu Sebelum dan Sesudah Kegiatan Pengabdian

\begin{tabular}{ccccc}
\hline \multirow{2}{*}{ No } & \multirow{2}{*}{ Kegiatan } & \multicolumn{3}{c}{ Pengetahuan } \\
\cline { 3 - 5 } & & Baik & Cukup & Kurang \\
\hline 1 & Sebelum kegiatan pengabdian & $0 \%$ & $100 \%$ & $0 \%$ \\
2 & Setelah kegiatan pengabdian & $85 \%$ & $15 \%$ & $0 \%$ \\
\hline
\end{tabular}

Dari tabel tersebut dapat dijelaskan bahwa sebelumnya kader posyandu mengerjakan soal pre test untuk mengetahui sejauh mana pemahaman kader mengenai pelaksanaan kegiatan posyandu dengan hasil seluruh kader mempunyai pengetahuan yang cukup mengenai Kegiatan Posyandu (100\%). Kemudian setelah pre test diberikan informasi kepada kader mengenai kegiatan posyandu diantaranya tentang tujuan posyandu, kegiatan pokok posyandu, kriteria kader posyandu dan pelaksanaan kegiatan posyandu. Pada saat diberikan informasi anggota merespon dengan baik apa yang disampaikan. Setelah diberikan informasi dilanjutkan dengan mengerjakan soal post test dengan hasil terdapat peningkatan yaitu sebagian besar kader memiliki pengetahuan yang baik mengenai pelaksanaan kegiatan posyandu (85\%).

Kegiatan pendampingan posyandu bayi dan balita telah dilaksanakan dengan hasil sudah dilaksanakan kegiatan pendampingan kepada kader pada saat melaksanakan kegiatan posyandu dan kader sudah dapat melaksanakan tugasnya dengan baik.

Dengan adanya pelatihan dan pembinaan keterampilan yang memadai bagi kader menyebabkan peningkatan pemahaman tugas kader dan peningkatan peran kader dalam melaksanakan tugasnya. Hal ini menjadi keberhasilan posyandu tak lepas dari kerja keras kader yang dengan sukarela mengelola posyandu di wilayahnya masing-masing.
1. Terlaksananya kegiatan pendampingan posyandu bayi dan balita di RW II Kelurahan Bendan Dhuwur Kecamatan Gajah Mungkur Kota Semarang.

2. Peningkatan Pengetahuan kader tentang Posyandu di RW II Kelurahan Bendan Dhuwur Kecamatan Gajah Mungkur Kota Semarang.

\section{REFERENSI}

Departemen Kesehatan RI. Pedoman Umum Pengelolaan Posyandu. Jakarta. 2006.

Departeman Kesehatan RI. Posyandu. Jakarta. DepKes RI. 2006.

Departemen Kesehatan RI. Revitalisasi Posyandu Direktorat Kesehatan Komunitas. Jakarta. 2005.

Kementrian Kesehatan RI. Buku Panduan Kader Posyandu. Jakarta. 2011.

Kementrian Kesehatan RI. Pedoman Pelaksana Posyandu. Sekjen Kementrian Kesehatan RI. Jakarta. 2011

Pokjanal Posyandu, Pedoman Pengelolaan Posyandu. Jakarta : Pokjanal Posyandu. 2006

\section{SIMPULAN}

Berdasarkan tujuan yang ingin dicapai dalam kegiatan pengabdian masyarakat ini, maka kesimpulan yang dapat diambil adalah : 